FACTA UNIVERSITATIS

Series: Economics and Organization Vol. 16, $\mathrm{N}^{\mathrm{o}} 1,2019$, pp. 49 - 58

https://doi.org/10.22190/FUEO1901049S

Preliminary Communication

\title{
THE ROLE OF HUMAN CAPITAL IN ENTREPRENEURIAL INNOVATIVENESS: EVIDENCE FROM SERBIA
}

\author{
UDC 005.961:005.914.3]:005.336.4(497.11)
}

\section{Marijana Simić, Marko Slavković}

University of Kragujevac, Faculty of Economics, Serbia

\begin{abstract}
Many studies in previous years indicate that human capital is a key element in explaining economic activity. Human capital refers to the knowledge, skills and abilities of employees and it is the most important part of the intangible assets of a company. In fact, the phenomenon of human capital is insufficiently examined in the context of entrepreneurial venture. Therefore, the purpose of this paper is to determine the role of human capital in achieving entrepreneurial innovativeness, while the relevant determinants of human capital are formal and non-formal education, lifelong learning, previous experience, and entrepreneurial self-efficacy. So, the main goal of this paper is to reveal the existence and nature of relationship between human capital and innovativeness of entrepreneurial firms in the Republic of Serbia, not older than 5 years. The results of the conducted statistical analyzes indicate that the defined hypotheses are partially confirmed. Actually, some of the human capital's determinants have a statistically relevant influence on the innovativeness of the observed entrepreneurial firms. The relevance of these results is justified by the fact that the information obtained through research, can be used to implement a more efficient and effective human resources management system in entrepreneurial ventures.
\end{abstract}

Key words: human capital, start up, entrepreneur, entrepreneurial innovativeness, Serbia

JEL Classification: M21, D22, O32

\section{INTRODUCTION}

In today's business environment, entrepreneurship appears as a significant lever of economic restructuring, its fundamental development resource, and entrepreneurs are classified as initiators and bearers of innovative changes (OECD, 1998). According to

Received November 22, 2018 / Revised February 06, 2019 / Accepted February 12, 2019

Corresponding author: Marijana Simić

Faculty of Economics Kragujevac, Liceja Kneževnine Srbije 3, 34000 Kragujevac, Serbia

E-mail: marijana.simic.2004@gmail.com 
Schumpeter, entrepreneurs' primary task is creative destruction, as they constantly provoke the status quo in search of a potential business opportunity. The basis of identifying business opportunities, as the initial phase of the entrepreneurial process, is in the creation of changes, the emergence of new firms, products, or services. Accordingly, innovation is classified as a specific entrepreneurial tool, the means by which changes become a possibility for performing various production or service activities (Drucker, 1996).

Innovation is often associated with human capital, which is also the case in explaining the entrepreneurial process, the way of doing business, and the problem of survival of entrepreneurial firms. The entrepreneur faces a particular challenge of securing a superior position on the market in relation to large, established enterprises. In the sea of rivals, the primary condition of survival is the formulation and implementation of a strategy that will lead to superior or average business performance. It is certain that the necessary prerequisite for survival is the exploitation of intangible assets, that is, human capital, in order to generate a unique competitive advantage (Scarborough \& Zimmerer, 2003). People and their resources, such as knowledge, skills, and abilities (Hayton, 2005), are an important source of innovation and strategic renewal (Bontis, 1998). Accordingly, entrepreneurs are expected to respond quickly, use their competences, creativity, and other intangible resources, and ensure the construction and implementation of simple, transparent, and certainly innovative solutions (Sanchez-Gutierrez et al., 2016), in order to create greater value for the customer.

The purpose of this paper is to identify the impact of human capital determinants on the innovativeness of entrepreneurial firms. The research was conducted to answer the following question: do entrepreneurs' education, previous experience and self-efficacy have a statistically significant impact on the innovativeness of new ventures in the Republic of Serbia? Therefore, the primary data was collected from owner/managers of entrepreneurial firms in the Republic of Serbia, not older than 5 years.

This article consists of several sections. After introductory remarks, the following section is devoted to a brief review of literature in two directions: first, it refers to a review of contemporary trends in entrepreneurship and entrepreneurial innovation, with particular reference to linking given phenomena to the human resources management system; second, it is devoted to explaining the phenomenon of human capital and its basic dimensions, which at the same time represent the basic criteria of the value of human capital. Thereafter, an insight into the research methodology is given, which includes a sample structure, as well as variables incorporated within a given research model. The next section is dedicated to presenting research results. Finally, a discussion of the results of statistical analysis was provided, as well as concluding observations.

\section{LITERATURE REVIEW}

\subsection{Entrepreneurship and entrepreneurial innovativeness}

Entrepreneurship, as a scientific area, is about the identification of ways in which to discover and exploit opportunities for creating future products and services (Shane \& Venkataraman, 2000). The key to the success of modern entrepreneurs rests on their vigilance and readiness to identify the opportunity to secure market position. Innovation forms the basis of the perceived entrepreneurial opportunity and the entrepreneurial process itself (Covin \& Miles, 1999; Schumpeter, 1942). 
Research in the field of entrepreneurship emphasizes that the achievement motivation is often the main cause of the individual's determination to be excused in "entrepreneurial waters," which is at the same time one of the key indicators of the difference between entrepreneurs and non-entrepreneurs (Poon et al., 2016). In addition to identified uncertainties, entrepreneurs face wide range of threats and challenges such as: insufficient availability of financial resources, lack of managerial skills, insufficiently competent employees, lack of relevant knowledge and skills, outdated production technology, poor infrastructure, rigid tax system, lack of state support, and institutional ineffectiveness (Khalique et al., 2015).

The initial step in understanding the entrepreneurial process is recognizing the entrepreneur as the main actor of the entire process and his/her characteristics and behaviour as relevant factors of the new venture success. The basic characteristics that classify an individual as an entrepreneur are: motivation to discover, evaluate and exploit entrepreneurial opportunities; (2) readiness to show initiative and creativity; (3) readiness to organize and transform resources; (4) accepting risk and failure (Poon, et al., 2016). In addition, knowledge, skills and abilities are emphasized, whether they are born or acquired, because they represent halfway to the establishment of an entrepreneurial venture, which in the end can result in its success (Matricano, 2016).

The context in which there are new ventures can possibly be divided into two perspectives: the discovery and creation perspective (Jones and Barnir, 2019). In line with the challenges within the discovery perspective, entrepreneurs are required to know the resources they have and have them appropriately used in order to effectively exploit the identified opportunity. To overcome obstacles along the way, entrepreneurs are expected to find and employ human resources that possess the specific skills and abilities necessary for a new venture (Alvarez and Barney, 2007). On the other hand, within the perspective of creation, general knowledge is more relevant in relation to specific knowledge and skills of individuals. Namely, entrepreneurs are committed to invent and develop products and services that are not known to companies within the given industry. In this way they support the building of innovative capacities, and due to the growing degree of risk and uncertainty, the need for individuals with general knowledge and skills from different fields is realized (Jones and Barnir, 2019).

\subsection{Human capital}

Knowledge and skills result from investing in human capital (Becker, 1964), but also form part of the innovation process. In a broader sense, innovativeness means a system of organized and purposeful activities aimed at creating change, while the result of this process is innovation (Janošević \& Dženopoljac, 2016). The essence of innovation is the implementation of changes, which is why entrepreneurs are expected to explore the sources of innovation, changes, and symptoms that signal a chance for the realization of successful innovation (Drucker, 1996). The importance of implementing the mentioned changes of existing activities through innovation is reflected in the fact that the entrepreneur in this way strives to achieve competitive advantage and improve business performance.

Plenty of evidence points to the importance of human capital, as personal entrepreneurial assets, when recognizing and developing a business opportunity (Davidsson \& Honig, 2003; Shane, 2000; Shepherd \& DeTienne, 2005). Based on theoretical assumptions, it can be concluded that individuals with more or higher quality human capital achieve better performance (Becker, 1964). In line with these findings, what follows below is the analysis of the forms of human capital as an important determinant of entrepreneurial activity, as well as an overview of previous research on their impact on the performance of entrepreneurial firms. 


\subsubsection{Education}

Education includes the accumulation of explicit knowledge, skills, and values (Becker, 1964), or a wide range of cognitive and non-cognitive elements, which define the outcomes of entrepreneurial activity (Davidsson \& Honig, 2003). The importance of acquiring knowledge, abilities, and skills is reflected in the context of the discovery and exploitation of business opportunities. Analytical skills, understanding of market conditions, and general and specific knowledge can contribute to the building of self-confidence and easier overcoming of problems in the early stage of development of new ventures, as well as more efficient entrepreneurial activity (Parker, 2009). Therefore, it is evident that a higher level of formal education positively affects the likelihood of starting an entrepreneurial venture (Cooper et al., 1994; Rotefoss \& Kolvereid, 2005), and, thus, facilitates the process of performing entrepreneurial activity.

The results of the research carried out in this field (Peña, 2002) show that most firms that record growth in sales, employees, and profits have entrepreneurs with university education, who show particular interest in business education programs. From the perspective of general human capital, organizational performance of new ventures can be enhanced if the entrepreneur and key employees have a higher level of education. Approximately, the higher level of education implies the accumulation of relevant knowledge and skills, among which, above all, problem-solving skills, as well as the appropriate combination of commitment, motivation, and discipline stand out. The field of education defines the degree of innovativeness and flexibility, as the basic preconditions for the establishment and survival of entrepreneurial ventures. In accordance with the given theoretical assumptions, the following hypothesis is defined:

H1: Entrepreneurs' education has a statistically significant impact on the new venture innovativeness.

\subsubsection{Previous experience}

Experience as a way of informal acquisition of knowledge and skills can be an important determinant that increases the likelihood of starting entrepreneurial activity (Sena et al., 2012). Experience involves storing a large amount of information in the individual's memory, which can later be used to create something new. Each individual has a unique combination of available information, which is an essential reason why some ideas occur to some people, and to others do not. Consequently, more experience, which an individual has in a particular field, is more likely to identify a new business opportunity (Davidsson \& Honig, 2003).

Empirical research provides some kind of evidence of the impact of experience on various aspects of entrepreneurial activity. Stuart and Abetti (1990) emphasize that previous experience is an important determinant of the initial success of new technical ventures. The analysis of success factors leads to the conclusion that not only the nature of the experience, but also its heterogeneity, including relevant knowledge and skills in different functional areas and past ownership experience, are relevant indicators of entrepreneurial success (Cooper et al., 1994). Moreover, experience in activities that are important for managing the venture, such as leadership experience, prolongs the market life of a firm (Rotefoss \& Kolvereid, 2005). In addition, there is evidence that firms established by entrepreneurs with longer work experience have more employees (Bosma et al., 2004). In accordance with the given theoretical and empirical evidence, it is possible to formulate the following hypothesis:

$\mathrm{H} 2$ : Entrepreneurs' previous experience has a statistically significant impact on the new venture innovativeness. 


\subsubsection{Entrepreneurial self-efficacy}

Self-efficacy implies a subjective self-assessment of one's own abilities to achieve the set goals and a certain level of performance. This type of self-perception is based on the subjective experience of personal competencies in the realization of different goals, rather than on real knowledge and skills (Bandura, 1977). In the field of entrepreneurship, the concept of self-efficacy has a significant impact when deciding to set up a new venture. The perceived self-efficacy in performing a specific task is an important determinant in the analysis of career choice.

Individuals who have been successful in different situations in the past are more likely to positively perceive their own abilities, resulting in the so-called high general self-efficacy. Although there is no explicit evidence that the general self-efficacy of entrepreneurs affects new venture performance, it is suggested that self-efficacy significantly defines the entrepreneur's intentions and activities (Boyd \& Vozikis, 1994). In addition, according to empirical results, it is possible to make the following conclusion: (1) self-efficacy is a relevant determinant in determining the difference between entrepreneurs and non-entrepreneurs (Chen et al., 1998), (2) there is a positive link between the perception of entrepreneurs' personal competencies and new venture performance (Chandler \& Jansen, 1992), and (3) the level of self-efficacy also identifies the opportunities for new venture growth (Baum \& Locke, 2004).

The evaluation of self-efficacy not only determines the choice of individual activities, but also the level of persistence and tendency for innovative behaviour. Where there are barriers on the path to achieving goals, individuals with a high level of self-efficacy make more efforts to overcome the perceived obstacles, rather than individuals with a low degree of self-efficacy. Consequently, the level of entrepreneurial self-efficacy determines their willingness to take the challenge of introducing new products and manage risky projects (Poon et al., 2016). Given the above, it is possible to set the following hypothesis:

H3: Entrepreneurial self-efficacy has a statistically significant impact on the new venture innovativeness.

\section{RESEARCH METHODOLOGY}

In order to examine a role of human capital determinants and their impact on the innovativeness of entrepreneurial firms, the original research was carried out. In this particular study, a convenience sample was applied. The sample consisted of entrepreneurs who have started their business in the previous 5 years. According to evidence of the Business Registers Agency 310 active entrepreneurial firms are identified. 121 respondents were willing to fulfil the questionnaire and this gives response rate of $39 \%$.

As for the structure of the sample, the largest number of entrepreneurial firms belonged to the service sector (51\%), followed by ventures in the trade sector (29\%), and the rest was within the production sector (20\%). The size of the business was determined by the number of employees in the entrepreneurial firm. Since the world economic literature describes entrepreneurial firm as an approximation to a new and small firm, the data collected during research fully corresponds to the above assumptions. In particular, out of the total number of firms included in the sample, as many as $89 \%$ had 2 to 9 employees, and only $11 \%$ had 10 or more employees.

The collection of primary data relied on a questionnaire as the survey instrument. The questionnaire was composed of questions defined in the form of statements, which measure 
the degree of respondents' agreement with the given statements (Table 1). To measure the agreement, a summarized 5-point Likert scale was used, ranging from 1 "I completely disagree" to 5 "I completely agree".

The education variable is measured by using 7 items. Example items are "Knowledge acquired through formal education is useful for daily work in your company.", "You have attended some kind of training that is relevant to performing your company's basic and other activities." and "Through formal and informal connections with experts outside the firm you acquire new knowledge and information important for your business."

Previous experience variable is measured by using the respondent's subjective perceptions. The respondents were asked to evaluate their previous experience by using 5 items. Example items are "You have previous ownership experience which contributes to your current business.", "You have previous managerial experience which contributes to your current business." and "You have previous experience in running a team (projects etc.) that contributes to the successful realization of work tasks."

Self-efficacy variable is measured as a human capital determinant by using 10 items. Example items are "You believe that you are able to develop a new product/service.", "You believe that you are ready to work in crisis situations." and "You are sure that you can achieve your goals."

Entrepreneurial innovativeness as a dependent variable is measured by using 10 items. Example items are "In the process of solving the problem, you are always ready to apply alternative solutions.", "Trying to view the identified problem from different angles." and "When performing work tasks, you often apply new, unusual and innovative solutions."

The measured determinants of human capital represented independent variables in the paper and can be classified as follows: education, previous experience, and self-efficacy. Part of the questionnaire relating to human capital determinants was compiled on the basis of a survey conducted by Davidsson, P. and Honig, B. (2003), Bosma, N., van Praag, M., Thurik, R. and de Wit, G. (2004) and Moon, Y. J. and Kym. H. G. (2006). The part of the questionnaire measuring the innovativeness of entrepreneurial firms was based on the work by Wach, D., Stephan, U. and Gorgievski, M. (2015), who analyzed business performance in 185 German entrepreneurial ventures, and the work by Dess, G. G., Lumpkin, G. T. and Covin, J. G. (1997), who analysed strategic aspects of the entrepreneurial venture, with a focus on business performance.

Statistical data processing was performed with the computer support of the Statistical Package for Social Sciences IBM SPSS Statistics, Version 23. In order to determine statistical significance, the confidence levels $\alpha=0.01, \alpha=0.05 \dot{\alpha}=0.1$ were used.

\section{RESEARCH RESULTS}

The reliability and consistency of the statements was measured using the Cronbach's alpha coefficient, where the values of this coefficient above 0.7 indicate high reliability and consistency (DeVellis, 2003). The value of Cronbach's alpha ranged from 0,800 to 0,923, indicating a very high level of internal consistency of statements.

In addition to the reliability analysis carried out, aggregate indicators, such as arithmetic mean and standard deviation, were calculated. The values of arithmetic mean indicate respondents' favourable attitudes regarding the observed determinants of human capital and the innovativeness of new ventures. Entrepreneurs best rated the innovativeness indicator (mean $=3.8545)$, and they considered that the most important determinant of human capital 
was self-efficacy (mean $=4.2355)$, while the highest standard deviation from the arithmetic mean was recorded with variable previous experience $(0.86048)$.

Table 1 Descriptive statistical analysis

\begin{tabular}{lccc}
\hline Variables & Cronbach's alpha & Arithmetic mean & Standard deviation \\
\hline Education & 0.828 & 3.8477 & 0.78457 \\
Previous experience & 0.800 & 3.4595 & 0.86048 \\
Self-efficacy & 0.917 & 4.2355 & 0.64716 \\
Innovativeness & 0.923 & 3.8545 & 0.72641 \\
\hline \multicolumn{2}{c}{ Source: Authors' research }
\end{tabular}

In order to test the hypotheses, a regression model was created, examining the nature and strength of the relationship between human capital determinants and innovativeness. If the characteristics of this regression model are observed, it is noted that the model is of good quality, since the value of $R^{2}$ is 0,663 , meaning that changes in the values of innovativeness of new ventures are explained in $66.3 \%$ of cases by changes in the values of independent variables.

The presented results of the multiple regression analysis (Table 2) show that education and entrepreneurial self-efficacy have a significant impact on innovativeness. However, previous experience has no statistically relevant influence on the analyzed dependent variable. The variance inflation factor is, in this case, also greater than 5 , which indicates that multicollinearity is not a problem.

Table 2 Results of multiple regression analysis (dependent variable: innovativeness)

\begin{tabular}{lccc}
\hline Independent variables & $\beta$ & $\mathrm{t}$ & sig. \\
\hline Education & 0.444 & 5.467 & $0.000^{* * *}$ \\
Previous experience & -0.040 & -0.659 & 0.511 \\
Self-efficacy & 0.453 & 5.791 & $0.000^{* * *}$ \\
\hline Note: ${ }^{* * *}$ The value is significant at $\mathrm{p}<0.01^{* *}{ }^{* *}$ The value is significant at $\mathrm{p}<0.05$. \\
${ }^{*}$ The value is significant at $\mathrm{p}<0.1 . \mathrm{R}^{2}=0,663 ; \mathrm{F}=76.682^{* * *}(\mathrm{p}<0.01)$. \\
\multicolumn{4}{r}{ Source: Authors ${ }^{*}$ research }
\end{tabular}

\section{DISCUSSION AND CONCLUSION}

Substantial changes that occurred during the scientific and technological revolution, that is, in the post-industrial society, metaphorically called "knowledge era", put emphasis on the evaluation of intangible resources, or human capital. Human capital, as the most important part of intangible assets of an enterprise, encompasses a wide range of intangible resources, such as knowledge, skills, abilities, and other personal attributes of the individual. The entrepreneur, as the main actor of the entrepreneurial process, has a kind of combination of intangible resources, accumulated knowledge, skills, and abilities. Since at the beginning of a new venture the entrepreneur usually faces the problem of the lack and limitation of financial and material resources, the main advantage over the existing rivals on the market lies in their human capital. By using available resources, the entrepreneur seeks to create innovation, in the form of better, more reliable, and more attractive products and services, which provide greater value for the customer. 
In accordance with the above assumptions, there are three hypotheses in the paper. The first hypothesis seeks to point to the necessity of having a relevant level and degree of education in order to achieve a greater degree of innovativeness in the performance of entrepreneurial activity. The results of the conducted statistical analyses show that, in case of analyzed new ventures, the educational profile of the entrepreneur has a statistically significant positive influence on innovativeness. Accordingly, we fail to reject the first research hypothesis, as confirmed by Robson, P.J.A., Akuetteh, C.K., Westhead, P. \& Wright, M. (2012).

The second hypothesis was set in order to determine the impact of the entrepreneur's previous experience on the innovativeness of the new venture. Despite the given theoretical indications, which clearly indicate the importance of previous experience for the establishment and survival of the entrepreneurial venture, research has shown that there is no statistically significant influence of the entrepreneur's experience on the level of innovativeness of the new venture. Therefore, the second hypothesis has been rejected. However, the third hypothesis, formulated in order to determine the influence of entrepreneurial self-efficacy on the innovativeness of the venture, failed to be rejected, so the results of the research indicate the existence of statistically relevant impact of the entrepreneurial self-efficacy on the innovativeness of the new venture, as confirmed by Poon, M.L., Ainuddin, R.A. \& Haji Junit, S. (2016).

The general conclusion is that certain human capital determinants affect the innovativeness of the new venture. Education, as a human capital determinant, has an important statistical impact on innovativeness, which emphasizes the relevance of building an adequate education system, as an essential factor for tracing the path to the development of entrepreneurial activity.

Although the self-employment option is often referred to as the continuation of an individual's previous work, the research results suggest that previous experience gained has no statistically significant impact on innovativeness of the new venture. In fact, the reason for making an individual decision to delve into "entrepreneurial waters" is usually the need for independence and financial stability, and not the quantity and quality of previously acquired knowledge and information about the activity within which an individual wants to demonstrate their entrepreneurial abilities. Such a trend in our country results in a high rate of unsuccessful entrepreneurial firms, which is why it is important to apply a systematic approach when launching new ventures and implementing innovative solutions, primarily by encompassing previous experience as an important criterion for the selection of activity within which the venture is set up.

The last but not the least important determinant of human capital, entrepreneurial selfefficacy, implies subjective assessment of personal abilities and thus constitutes an important determinant of innovativeness of the new venture. This result is completely expected, since greater belief in one's own abilities defines not only the readiness of an individual to try an entrepreneurial activity, but also the overall tendency for innovative behaviour. Thus, the belief in one's own abilities is the key to entrepreneurial success, which generates additional energy for overcoming obstacles in the initial and later phases of the entrepreneurial process.

At the national economy level, the results emphasise the importance of developing an adequate education system, which through the development of human capital improves the innovation of individuals. Bearing in mind the fact that innovation is a key source for the creation of a new venture, the design of entrepreneurial-oriented education system at the macro level can affects the readiness of an individual to include in "entrepreneurial waters," which encourages the construction of an entrepreneurial culture. At the micro level, the implications of the obtained results are reflected in the fact that besides the level and field of education, it is important to invest 
in different training programs, which stimulates the development of business skills, resulting in a greater degree of self-efficacy. Human resources management, through training policies and training programs, can influence the development of individuals by increasing their potential for innovation and entrepreneurial behaviour. Since self-efficacy is an important determinant of entrepreneurial activity, as well as the assumption of building innovative capacities within the entrepreneurial venture, this creates a precipitous ground for establishing future new ventures.

Acknowledgement: This paper is part of an interdisciplinary research project (number 41010), financed by the Ministry of Education, Science and Technological Development of the Republic Serbia.

\section{REFERENCES}

Alvarez, S.A., \& Barney, J.B. (2007). Discovery and creation: Alternative theories of entrepreneurial action. Strategic entrepreneurship journal, 1 (1-2), 11-26.

Bandura, A. (1977). Self-efficacy: toward a unifying theory of behavioral change. Psychological review, 84 (2), 191 - 215.

Baum, J.R. \& Locke, E.A. (2004). The relationship of entrepreneurial traits, skill, and motivation to subsequent venture growth. Journal of applied Psychology, 89 (4), 587- 598.

Becker, G.S. (1964). Human capital: a theoretical analysis with special reference to education, New York: Columbia University Press for NBER.

Bontis, N. (1998). Intellectual capital: an exploratory study that develops measures and models. Management Decision, $36(2), 63-76$.

Bosma, N., Van Praag, M., Thurik, R. \& De Wit, G. (2004). The value of human and social capital investments for the business performance of startups. Small Business Economics, 23 (3), 227-236.

Boyd, N.G. \& Vozikis, G.S. (1994). The influence of self-efficacy on the development of entrepreneurial intentions and actions. Entrepreneurship theory and practice, 18, 63-63.

Chandler, G.N. \& Jansen, E. (1992). The founder's self-assessed competence and venture performance. Journal of Business Venturing, 7 (3), 223-236.

Chen, C., Greene, P. \& Crick, A. (1998). Does entrepreneurial Self-efficacy Distinguish Entrepreneurs from Managers Journal of Business Venturing, 13 (4), 295-316.

Cooper, A.C., Gimeno-Gascon, F.J. \& Woo, C.Y. (1994). Initial human and financial capital as predictors of new venture performance. Journal of business venturing, 9 (5), 371-395.

Covin, J.O. \& Miles, M.P. (1999). Corporate entrepreneurship and the pursuit of competitive advantage. Entrepreneurship Theory and Practice, 23 (3), 47-63.

Davidsson, P. \& Honig, B. (2003). The role of social and human capital among nascent entrepreneurs. Journal of Business Venturing, 18 (3), 301-331.

Dess, G.G., Lumpkin, G.T. \& Covin, J.G. (1997). Entrepreneurial strategy making and firm performance: Tests of contingency and configurational models. Strategic management journal, 18 (9), 677-695.

DeVellis, R. F. (2003). Scale Development: Theory and applications, 2nd edn, Thousand Oaks, California: Sage Publications.

Drucker, P. (1996). Inovacije i preduzetništvo [Innovation and Entrepreneurship]. Beograd: Grmeč.

Hayton, J.C. (2005). Competing in the new economy: the effect of intellectual capital on corporate entrepreneurship in high-technology new ventures. R\&D Management, 35 (2), 137-155.

Janošević, S. \& Dženopoljac, V. (2016). Inovativnost kao komponenta intelektualnog kapitala [Innovation as a component of intellectual capital]. In: Unapređenje konkurentnosti privrede Republike Srbije, Kragujevac: Ekonomski fakultet u Kragujevcu, 171-186

Jones, R.J. \& Barnir, A. (2019). Properties of opportunity creation and discovery: Comparing variation in contexts of innovativeness. Technovation, 79, 1-10.

Marvel, M.R. \& Lumpkin, G.T. (2007). Technology entrepreneurs' human capital and its effects on innovation radicalness. Entrepreneurship Theory and Practice, 3 (6), 807-828.

Moon, Y.J. \& Kym. H.G. (2006). A Model for the Value of Intellectual Capital. Canadian Journal of Administrative Sciences, 23 (3), 253-269.

OECD (1998). Fostering Entrepreneurship: A Thematic Review. Paris: OECD.

Parker, S. (2009). The Economics of Entrepreneurship, Cambridge: Cambridge University Press. 
Peña, I. (2002). Intellectual capital and business start-up success. Journal of Intellectual Capital, 3 (2), 180-198.

Poon, M.L., Ainuddin, R.A. \& Haji Junit, S. (2016). Effects of Self-concept Traits and Entrepreneurial Orientation on Firm Performance. International Small Business Journal, 24 (1), 61-82.

Rotefoss, B. \& Kolvereid, L. (2005). Aspiring, nascent and fledgling entrepreneurs: an investigation of the business start-up process. Entrepreneurship \& Regional Development, 17 (2), 109-127.

Sanchez-Gutierrez, J., Mejia-Trejo, J., Vargas-Barraza, J.A. \& Vazquez-Avila, G. (2016). Intellectual capital, impact factor on competitiveness: manufacturing industry SMEs in Mexico. Measuring Business Excellence, 20 (1), 1-11.

Scarborough, N. M. \& Zimmerer, T. W. (2003). Effective Small Business Management an Entrepreneurial Approach, New Jersey: Pearson Education.

Schumpeter, J.A. (1942). Capitalism, socialism, and democracy, New York: Harper and Brothers.

Sena, V., Scott, J. \& Roper, S. (2012). Gender, borrowing patterns and self-employment: some evidence for England. Small Business Economics, 38 (4), 467-480.

Shane, S. \& Venkataraman, S. (2000). The promise of entrepreneurship as a field of research. Academy of Management Review, (25), 217-226.

Shane, S. (2000). Prior knowledge and the discovery of entrepreneurial opportunities. Organization Science, 11 (4), $448-469$.

Shepherd, D.A. \& DeTienne, D.R. (2005). Prior knowledge, potential financial reward, and opportunity identification. Entrepreneurship Theory and Practice, 29 (1), 91-112.

Stuart, R.W. \& Abetti, P.A. (1990). Impact of entrepreneurial and management experience on early performance. Journal of business venturing, 5 (3), 151-162.

Wach, D., Stephan, U. \& Gorgievski, M. (2015). More than money: Developing an integrative multi-factorial measure of entrepreneurial success. International Small Business Journal, 34 (8), 1098-1121.

\section{ULOGA LJUDSKOG KAPITALA U PREDUZETNIČKOJ INOVATIVNOSTI: EVIDENCIJA IZ SRBIJE}

Brojni su dokazi koji ukazuju da je ljudski kapital ključni element u objašnjavanju ekonomske aktivnosti. Ljudski kapital se odnosi na znanje, veštine $i$ sposobnosti zaposlenih $i$ predstavlja najvažniji deo nematerijalne imovine preduzeća. Identifikovani jaz u prethodnim empirijskim studijama je osnovni cilj ovog rada. Naime, fenomen ljudskog kapitala nije dovoljno istraživan u kontekstu preduzetničkog poduhvata. Stoga je cilj ovog rada da utvrdi ulogu ljudskog kapitala u postizanju preduzetničke inovativnosti, pri čemu su relevantne komponente ljudskog kapitala formalno i neformalno obrazovanje, celoživotno učenje, prethodno iskustvo i preduzetnička samo-efikasnost. Dakle, glavni cilj je utvrđivanje uticaja komponenti ljudskog kapitala na inovativnost preduzetničkih firmi u Republici Srbiji, koje nisu starije od 5 godina. Rezultati sprovedenih statističkih analiza ukazuju da su hipoteze delimično potvrđene. Zapravo, neke od komponenti ljudskog kapitala imaju statistički značajan uticaj na inovativnost posmatranih preduzetničkih firmi. Relevantnost ovih rezultata opravdana je činjenicom da se informacije dobijene istraživanjima mogu koristiti za implementaciju efikasnijeg i efikasnijeg sistema upravljanja ljudskim resursima u preduzetničkim poduhvatima.

Ključne reči: ljudski kapital, preduzetnički poduhvati, preduzetnik, preduzetnička inovativnost, Srbija 